Prepared in cooperation with the

Bureau of Land Management

Hydrogeologic Framework and Estimates of Ground-Water Volumes in Tertiary and Upper Cretaceous Hydrogeologic Units in the Powder River Basin, Wyoming

Scientific Investigations Report 2005-5008 


\section{Hydrogeologic Framework and Estimates of Ground-Water Volumes in Tertiary and Upper Cretaceous Hydrogeologic Units in the Powder River Basin, Wyoming}

By Kurt Hinaman

Prepared in cooperation with the

Bureau of Land Management

Scientific Investigations Report 2005-5008 


\section{U.S. Department of the Interior \\ Gale A. Norton, Secretary \\ U.S. Geological Survey \\ Charles G. Groat, Director}

U.S. Geological Survey, Reston, Virginia: 2005

For sale by U.S. Geological Survey, Information Services

Box 25286, Denver Federal Center

Denver, CO 80225

For more information about the USGS and its products:

Telephone: 1-888-ASK-USGS

World Wide Web: http://www.usgs.gov/

Any use of trade, product, or firm names in this publication is for descriptive purposes only and does not imply endorsement by the U.S. Government.

Although this report is in the public domain, permission must be secured from the individual copyright owners to reproduce any copyrighted materials contained within this report. 


\section{Contents}

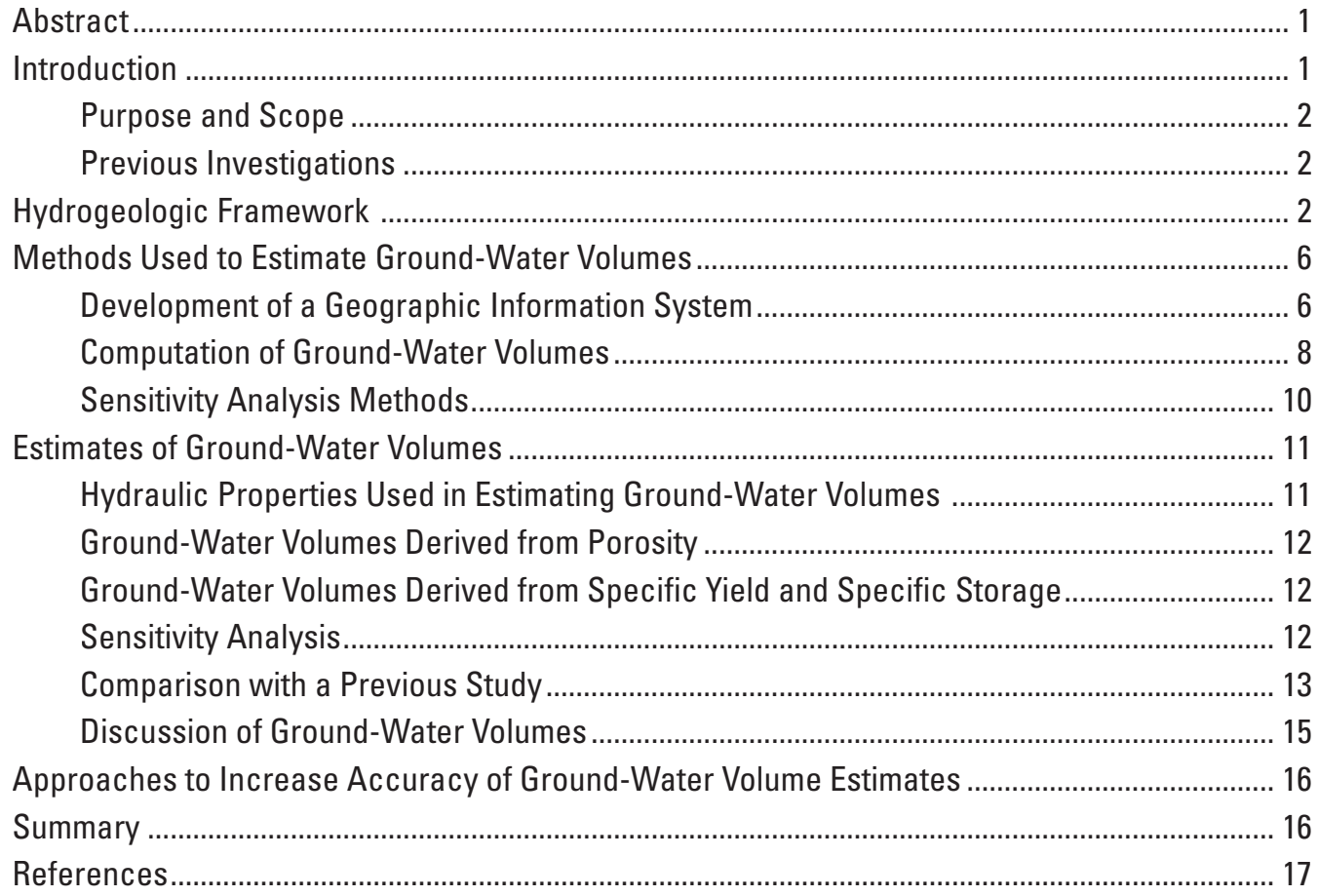

\section{Figures}

1. Map showing hydrogeologic units of the Powder River structural basin in Wyoming and Montana

2. Generalized stratigraphic column of Tertiary and upper Cretaceous formations in the southern Powder River structural basin, Wyoming (modified from Flores and Bader, 1999)

3. West to east hydrogeologic section of the Tertiary and upper Cretaceous hydrogeologic units showing the asymmetric nature of the Powder River structural basin, Wyoming

4. Sketch showing example contours, outcrop, and triangulated irregular networks (TINS). A, original contours from Lewis and Hotchkiss (1981), B, TINS based on original contours, $C$, original contours and contours extended and added by manual methods, and $D$, revised TINS based on extended and added contours.

5. Schematic showing relations among land surface, water table, hydrogeologic units, and saturated section of the hydrogeologic units in the study area, Powder River structural basin, Wyoming

6. Sketch showing how the original values of contours $(A)$ were increased by 10 percent to form another set of values $(B)$ that were used to create TINS to study the effect of a systematic error in contour values.

7. Sketch showing how the values of inflection lines were changed in the center of the closed contour, with the value used in the base analysis $(A)$, and showing the changed value of the inflection line $(B)$, which was used in the sensitivity analysis .... 11 


\section{Figures-Continued}

8. Sensitivity of calculated ground-water volumes to selected factors used to calculate ground-water volumes.

\section{Tables}

1. Hydraulic properties of hydrogeologic units in the Powder River Basin used to estimate ground-water volumes

2. Estimated ground-water volumes in Tertiary and upper Cretaceous hydrogeologic units in the Powder River Basin based on porosity

3. Estimated ground-water volumes in Tertiary and upper Cretaceous hydrogeologic units in the Powder River Basin based on specific yield and specific storage.

4. Sensitivity of calculated ground-water volumes to selected factors used to calculate the ground-water volumes

5. Comparison of estimates of available volumes of ground water from Applied Hydrology Associates, Inc. and Greystone Environmental Consultants, Inc. (2002) to the estimates of ground-water volumes determined in this study from storativity factors 


\title{
Hydrogeologic Framework and Estimates of Ground-Water Volumes in Tertiary and Upper Cretaceous Hydrogeologic Units in the Powder River Basin, Wyoming
}

\author{
By Kurt Hinaman
}

\begin{abstract}
The Powder River Basin in Wyoming and Montana is an important source of energy resources for the United States. Coalbed methane gas is contained in Tertiary and upper Cretaceous hydrogeologic units in the Powder River Basin. This gas is released when water pressure in coalbeds is lowered, usually by pumping ground water. Issues related to disposal and uses of by-product water from coalbed methane production have developed, in part, due to uncertainties in hydrologic properties. One hydrologic property of primary interest is the amount of water contained in Tertiary and upper Cretaceous hydrogeologic units in the Powder River Basin. The U.S. Geological Survey, in cooperation with the Bureau of Land Management, conducted a study to describe the hydrogeologic framework and to estimate ground-water volumes in different facies of Tertiary and upper Cretaceous hydrogeologic units in the Powder River Basin in Wyoming.

A geographic information system was used to compile and utilize hydrogeologic maps, to describe the hydrogeologic framework, and to estimate the volume of ground water in Tertiary and upper Cretaceous hydrogeologic units in the Powder River structural basin in Wyoming. Maps of the altitudes of potentiometric surfaces, altitudes of the tops and bottoms of hydrogeologic units, thicknesses of hydrogeologic units, percent sand of hydrogeologic units, and outcrop boundaries for the following hydrogeologic units were used: Tongue River-Wasatch aquifer, Lebo confining unit, Tullock aquifer, Upper Hell Creek confining unit, and the Fox Hills-Lower Hell Creek aquifer. Literature porosity values of 30 percent for sand and 35 percent for non-sand facies were used to calculate the volume of total ground water in each hydrogeologic unit. Literature specific yield values of 26 percent for sand and 10 percent for non-sand facies, and literature specific storage values of $0.0001 \mathrm{ft}^{-1}$ (1/foot) for sand facies and $0.00001 \mathrm{ft}^{-1}$ for non-sand facies, were used to calculate a second volume of ground water for each hydrogeologic unit. Significant figure considerations limited estimates of ground-water volumes to two significant digits.
\end{abstract}

\begin{abstract}
A total ground-water volume of $2.0 \times 10^{14} \mathrm{ft}^{3}$ (cubic feet) was calculated using porosity values, and a total ground-water volume of $3.6 \times 10^{13} \mathrm{ft}^{3}$ was calculated using specific yield and specific storage values. These results are consistent with retention properties, which would have some of the total water being retained in the sediments.

Sensitivity analysis shows that the estimates of groundwater volume are most sensitive to porosity. The estimates also are sensitive to confined thickness and saturated thickness. Better spatial information for hydrogeologic units could help refine the ground-water volume estimates.
\end{abstract}

\section{Introduction}

The Powder River structural basin in Wyoming and Montana (fig. 1) is an important source of energy resources for the United States. Coalbed natural gas (Johnson and Flores, 1998; Miller, 1999; Montgomery, 1999) is contained in Tertiary and upper Cretaceous hydrogeologic units (fig. 2) in the Powder River structural basin. The Powder River structural basin is asymmetric, with the deepest part of the basin west of the basin center (fig. 3).

Coalbed natural gas, referred to as coalbed methane (CBM), is released when water pressure in coals is lowered, usually by pumping ground water (Rice and Nuccio, 2000). After this water is pumped out of the ground-water system it must be disposed. Many issues related to disposal and use of by-product water from CBM production have developed, in part due to the uncertainty of basic hydrologic and geochemical properties of Tertiary and upper Cretaceous hydrogeologic units, such as the volume of ground water in storage and the chemical composition of that water. Some studies have started to define these properties, such as groundwater chemistry (Rice and others, 2000, 2002; Bartos and Ogle, 2002), whereas other properties, such as the volume of ground water in the basin, remain poorly defined. One hydrologic property of primary interest is the amount of water contained in Tertiary and upper Cretaceous hydrogeologic units in the Powder River structural basin. 
The U.S. Geological Survey (USGS), in cooperation with the Bureau of Land Management (BLM), conducted a study to describe the hydrogeologic framework and to estimate ground-water volumes in different facies of Tertiary and upper Cretaceous hydrogeologic units in the Powder River structural basin in Wyoming. These estimates provide the BLM with information about the maximum possible amount of water that could be produced by CBM production in the Powder River structural basin over the next 10 to 15 years (U.S. Department of the Interior, 2002).

\section{Purpose and Scope}

The purpose of this report is to describe the hydrogeologic framework and to estimate ground-water volumes in Tertiary and upper Cretaceous hydrogeologic units in the Powder River structural basin in Wyoming. The sensitivity of ground-water volume estimates to various hydrologic properties also is described.

\section{Previous Investigations}

Many previous investigations have been done in the Powder River Basin and an exhaustive discussion of previous work is beyond the scope of this report. For a general overview of work, readers are referred to Bartos and Ogle (2002) which includes a review of previous geologic investigations. Another compilation of references is the 1999 assessment of coal in this area (Fort Union Coal Assessment Team, 1999). Additional information can be found in numerous guidebooks about the Powder River Basin or coalbed methane (Cooper and others, 1963; Diedrich and others, 1988; Miller, 1999; Schwochow and Nuccio, 2002).

\section{Hydrogeologic Framework}

In previous investigations, the name Powder River Basin has been used to refer to both a structural basin and a drainage basin. The structural basin and the drainage basin do not coincide and both are frequently used interchangeably to define the area. In this report, Powder River Basin refers to the structural basin. The Powder River Basin is an asymmetrical syncline formed during the Laramide orogeny (Late Cretaceous to early Tertiary age). The axis of the basin trends from southeast to northwest near the western margin of the basin (fig. 1), far from its geographic center. In Wyoming, the Powder River Basin is bounded by the Black Hills uplift in the northeast, the Hartville uplift in the southeast, the Laramie Mountains in the south, the Casper arch in the southwest, and the Bighorn Mountains in the west (fig. 1). The basin continues northward into Montana, where another structural feature, the Cedar Ridge anticline, separates it from the Williston Basin (not shown in fig. 1). The entire basin covers an area of more than 22,000 square miles (Flores and others, 1999).

Tertiary and upper Cretaceous hydrogeologic units within the Powder River Basin in Wyoming are the focus of this study. The Tertiary and upper Cretaceous formations that contain the hydrogeologic units of interest are described first in this section of the report.

The Lewis Shale and its equivalents (fig. 2), which are upper Cretaceous-age marine units (Steidtmann, 1993; Merewether, 1996), form the basal confining layer. Overlying this shale is the upper Cretaceous-age Fox Hills Sandstone, which represents a sandy shoreline as the seaway retreated to the northeast (Steidtmann, 1993; Mereweather, 1996), and the Lance Formation of which about one-third is composed of channel sandstones and the rest of the formation is finergrained interfluvial sedimentary rock (Conner, 1992). Crossbedding, channel orientation, and orientation of well-cemented sandstones having log-like forms show deposition from eastward-flowing streams on both sides of the Bighorn Mountains and on the east side of the Powder River Basin, indicating that those mountains had yet to emerge, and that the Powder River Basin had yet to form by the end of the Cretaceous period (Conner, 1992).

The lowest Tertiary unit is the Paleocene-age Fort Union Formation, which is subdivided into three members - the Tullock, Lebo Shale, and Tongue River Members (fig. 2). The Tullock Member is composed of about one-third channel sands and two-thirds finer grained overbank deposits (Brown, 1993). In the northwest part of the Powder River Basin, the Tullock Member contains carbonate clasts in its lowermost part, which are interpreted to mean that the Bighorn Mountains were starting to emerge during the time of its deposition (Brown, 1993). At the same time, coal-forming environments were forming and being deposited from the southeast to the northwest (Brown, 1993). The Lebo Shale Member is mainly a mudstone with some minor channel sands (Whipkey and others, 1991). The depositional environment for the Lebo Member was described as lacustrine by Ayers (1986), whereas others (summarized in Flores and Bader, 1999) indicate that fine-grained sediments are from the shedding of fine-grained marine Cretaceous shales from the rising Bighorn Mountains. The Tongue River Member contains considerable channel sandstones and coals. The Tongue River Member transitions to the Eocene-age Wasatch Formation with no distinct marker or lithologic change at the contact between the two units (Bartos and Ogle, 2002).

Some of the hydrogeologic units described in this report correspond with geologic formations, whereas other hydrogeologic units combine geologic formations, and other hydrogeologic units have contacts within stratigraphic units (fig. 2). This study uses terms for hydrogeologic units defined by Lewis and Hotchkiss (1981) and further described by Hotchkiss and Levings (1986). The uppermost hydrogeologic unit is the Tongue River-Wasatch aquifer, which averages 55 percent sand (Lewis and Hotchkiss, 1981). Below the Tongue RiverWasatch aquifer is the Lebo confining unit, which averages 


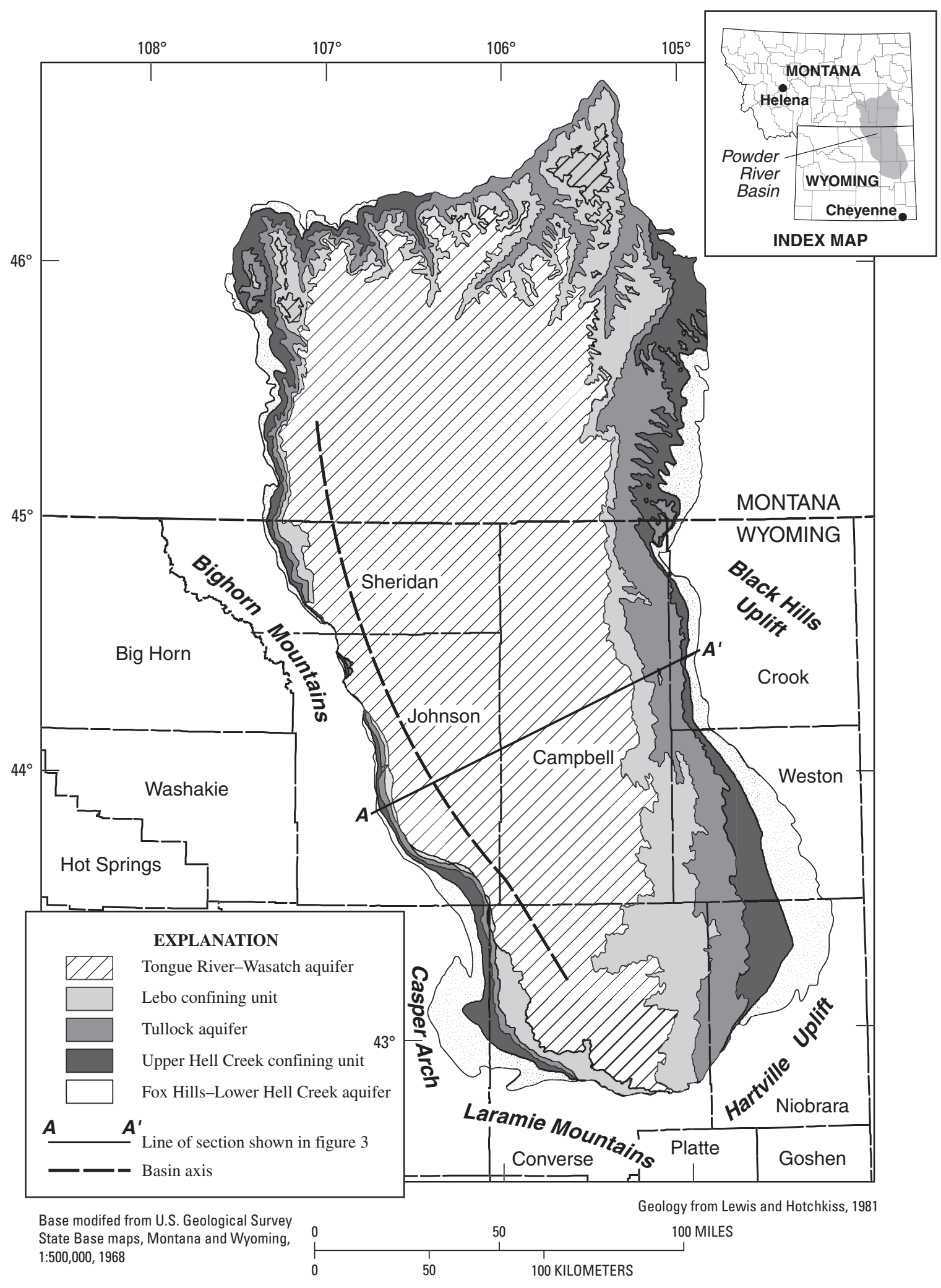

Figure 1. Hydrogeologic units of the Powder River structural basin in Wyoming and Montana. 


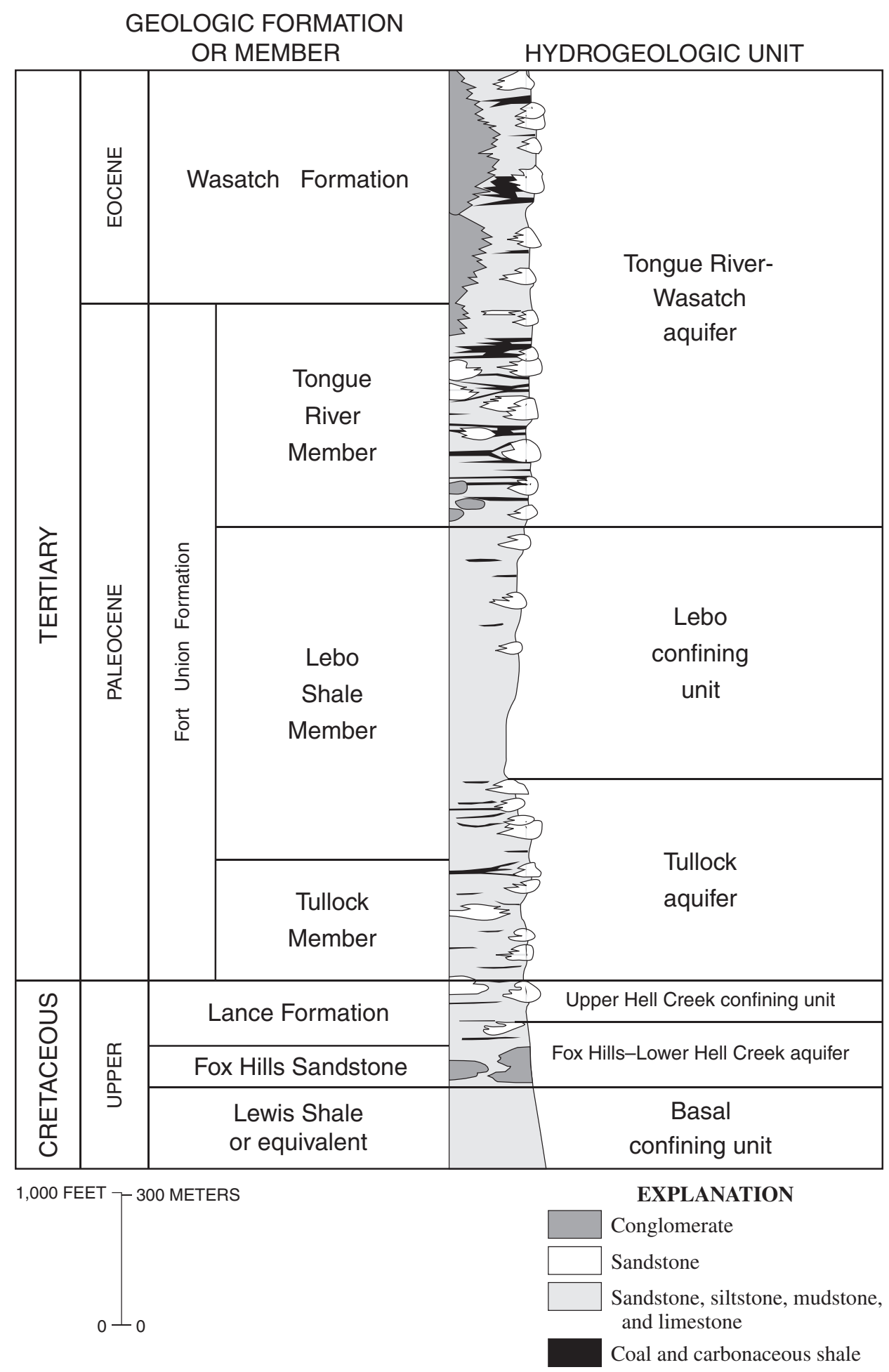

Figure 2. Generalized stratigraphic column of Tertiary and upper Cretaceous formations in the southern Powder River structural basin, Wyoming (modified from Flores and Bader, 1999). 
31 percent sand (Lewis and Hotchkiss, 1981); however, predominant mudstones give it confining unit characteristics. Below the Lebo confining unit is the Tullock aquifer, which includes basal sands of the Lebo Shale Member. This aquifer averages 53 percent sand (Lewis and Hotchkiss, 1981) and is confined at its base by the upper Hell Creek confining unit. This unit typically acts as a confining unit, but with sand content ranging from 9 to 88 percent, and a mean of 35 percent, wells completed in it can flow (Hotchkiss and Levings, 1986). This confining unit is the upper part of the Lance Formation in Wyoming. Below this unit is the basal aquifer of interest in this report, the Fox Hills-Lower Hell Creek aquifer. Average sand content is 50 percent and it is a good source of water in the Powder River Basin (Hotchkiss and Levings, 1986). This aquifer includes the lower part of the Lance Formation and the
Fox Hills Sandstone. At its base is the basal confining unit, the Lewis Shale, which is equivalent to the Bearpaw Shale in Hotchkiss and Levings (1986).

For all of the hydrogeologic units of interest, the general direction of ground-water flow is from south to north with the influence of the major rivers as discharge areas (Hotchkiss and Levings, 1986; Whitehead, 1996). In parts of the basin, this general direction of flow is influenced by a flow component from topographically high areas, such as the Bighorn Mountains to the west, Laramie Range to the south, and Black Hills to the east. An example is shown on the potentiometric map of the Wyodak-Anderson coal bed by Daddow (1986), which only shows the eastern limb of the flow system and has a more southeast to northwest flow pattern. From a more regional view, the general flow is from south to north.

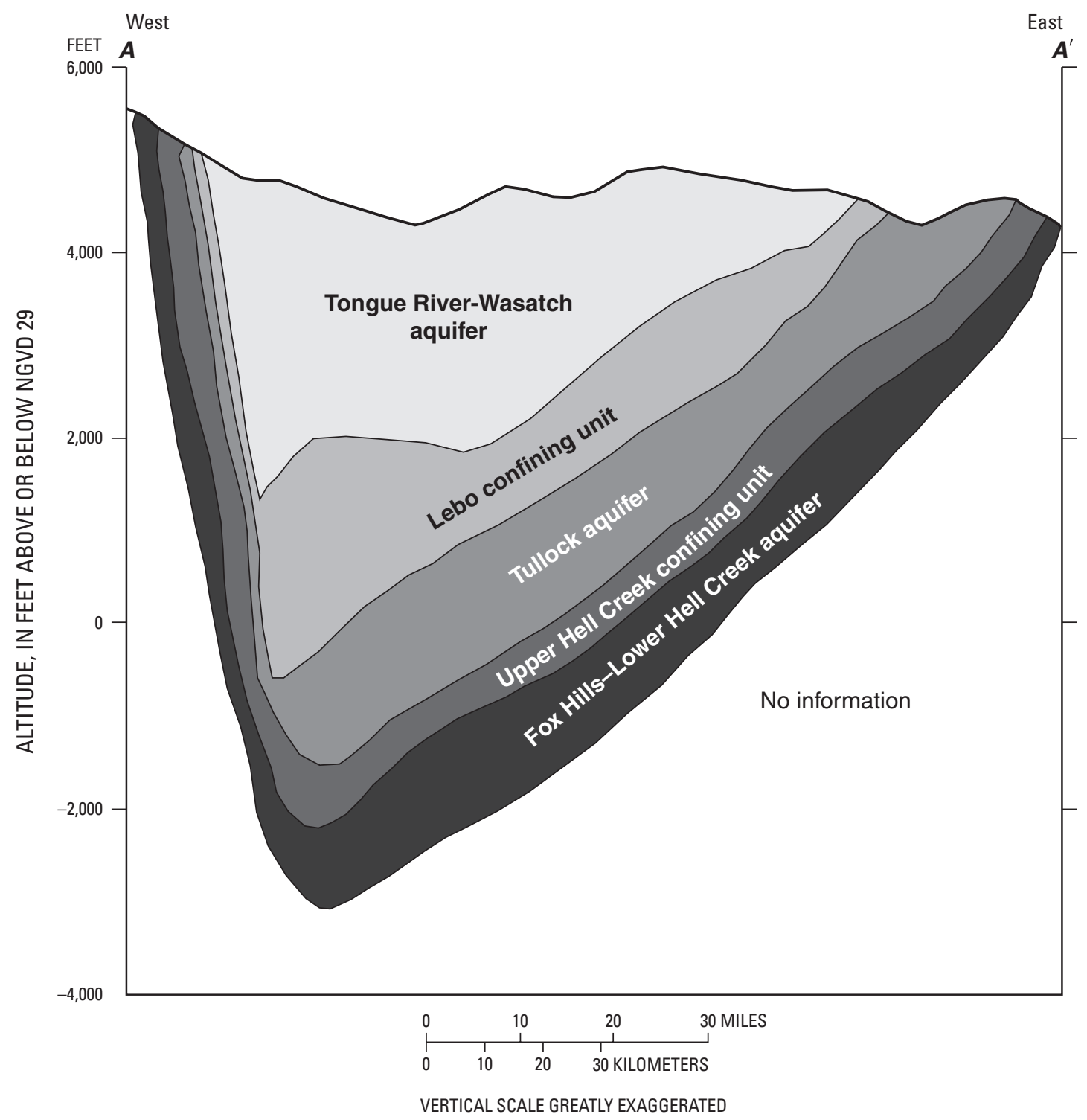

Figure 3. West to east hydrogeologic section of the Tertiary and upper Cretaceous hydrogeologic units showing the asymmetric nature of the Powder River structural basin, Wyoming. 


\section{Methods Used to Estimate Ground- Water Volumes}

Following is a description of methods used to estimate the volume of water in Tertiary and upper Cretaceous hydrogeologic units in the Powder River Basin in Wyoming. The first task was to develop a geographic information system (GIS) to display and utilize data sets for use in calculating volume estimates. The second task was to determine the volume of water. Estimates of ground-water volumes were determined by two methods: (1) a total volume based on porosity and saturated thickness, and (2) a volume that could be removed by pumping based on specific yield, specific storage, and saturated thickness. The hydraulic properties used in the estimates are described in the Hydraulic Properties Used in Estimating Ground-Water Volume section of this report. The third task was to determine the sensitivity of the ground-water volume estimates to the factors used to calculate these estimates.

\section{Development of a Geographic Information System}

Data were prepared for input into a GIS. Folded paper maps of three themes: (1) the altitude of the base of the hydrogeologic units (shown in fig. 3); (2) percent sand of each unit; and (3) the total thickness of each unit (Lewis and Hotchkiss, 1981) were carefully ironed to flatten creases caused by folds. Each map was then placed flat onto a large table and covered with transparent film. The theme of each map was traced onto a separate piece of transparent film along with at least nine registration points, which were either latitude and longitude tics, or locations of major cities or towns. Care was taken to ensure that each theme was bounded by tics. Separate themes, on transparent film, were taken to the University of Wyoming American Heritage Center in Laramie, Wyoming and scanned on a large format scanner. In GIS, a tic-point coverage was created and then the scanned images were imported and converted to grids. Additional themes of water levels for various hydrogeologic units were scanned and processed through the steps previously described. A map of the water table of the Tongue River-Wasatch aquifer (Hotchkiss and Levings, 1986) was traced onto transparent film along with registration points. Potentiometric surface maps of other hydrogeologic units (Hotchkiss and Levings, 1986) were prepared in a similar manner.

Each theme was converted to a grid, formatted for use in GIS, and georeferenced using ARCMAP ${ }^{1}$. The tic and grid coverages were imported, and the grid was zoomed to overlay the tic coverage. The georeferencing tool was used to add control points to the grid by clicking on a control point on the grid, then selecting the corresponding control point in the tic

\footnotetext{
${ }^{1}$ Copyrighted term of ESRI, Inc.
}

coverage. Grids were first registered on the outside of the grid, and final control points were registered inside of the grid. A third order polynomial was used to transform the grid, and the grid was rectified. The projection file of the tic coverage was copied for use as the projection file of the rectified grid. A new grid was created by selecting pixels in the rectified grid that represented contour lines, then converting the grid to a line coverage. The line coverage was edited by deleting unneeded tic marks and adding values to the contour lines. In a search for errors during verification of the results, some themes were converted to the scale and projection of the original paper maps. Paper copies of these maps were plotted, laid over the original maps on a light table, and any errors were corrected.

Coverage projections were changed to Albers equal-area projection, with a North American Datum of 1927 (NAD 27). All maps used feet as the units. Surfaces were then converted to triangulated irregular networks (TINS ${ }^{2}$. Arcs were used as the input coverage, the contour value (altitude, thickness, or percent sand, depending upon the theme) was used as the $\mathrm{z}$ factor, and the contours were used as hard lines.

To create a point coverage to sample the TINS, a grid was made from the polygon coverage of the Fox Hills Sandstone outcrop which has the outermost extent of the hydrogeologic units of interest. This grid was made with a cell size of 1,000 feet (ft) on a side, which was chosen as a compromise between detail and reasonable computation times (days). This grid was then converted to a point coverage, which was a series of 419,327 points with each point separated by $1,000 \mathrm{ft}$ from another point. The TINS of the themes were sampled in GIS by use of the "TINSPOT" command, which sampled the TIN at each point with the linear option. At each point the altitude of the base of the unit, the unit's thickness, and the percentage sand of the unit were sampled.

Considerable time was spent correcting negative values. Negative values were the result of contours from Lewis and Hotchkiss (1981) not extending to the outermost extent of the outcrop (fig. 4A). When TINS were made from these contours, the TINS did not extend past the outcrop areas (fig. 4B) and "no sample" values (-9999) were assigned to sample points. In these areas, contours were extended or added by manual methods past the outcrop extent (fig. 4C). Extended and added contours were used to make revised TINS, which extended past the outcrop extent (fig. 4D). When sampled, revised TINS then gave positive values.

Areas with structural arches, closed structural highs, and elongated or closed structural lows were a concern because the TIN process assigns a uniform value for all samples within these areas. Although having uniform values is a possible interpretation of a surface between contours with the same values, a more plausible interpretation is that there is an inflection point or line between two contours with the same values. Values would change between the last known contour and this inflection point or line, and then the rate of change would

${ }^{2}$ TINS and TIN are used somewhat interchangeably, with TIN usually referring to one theme, such as "a TIN of the water table." 

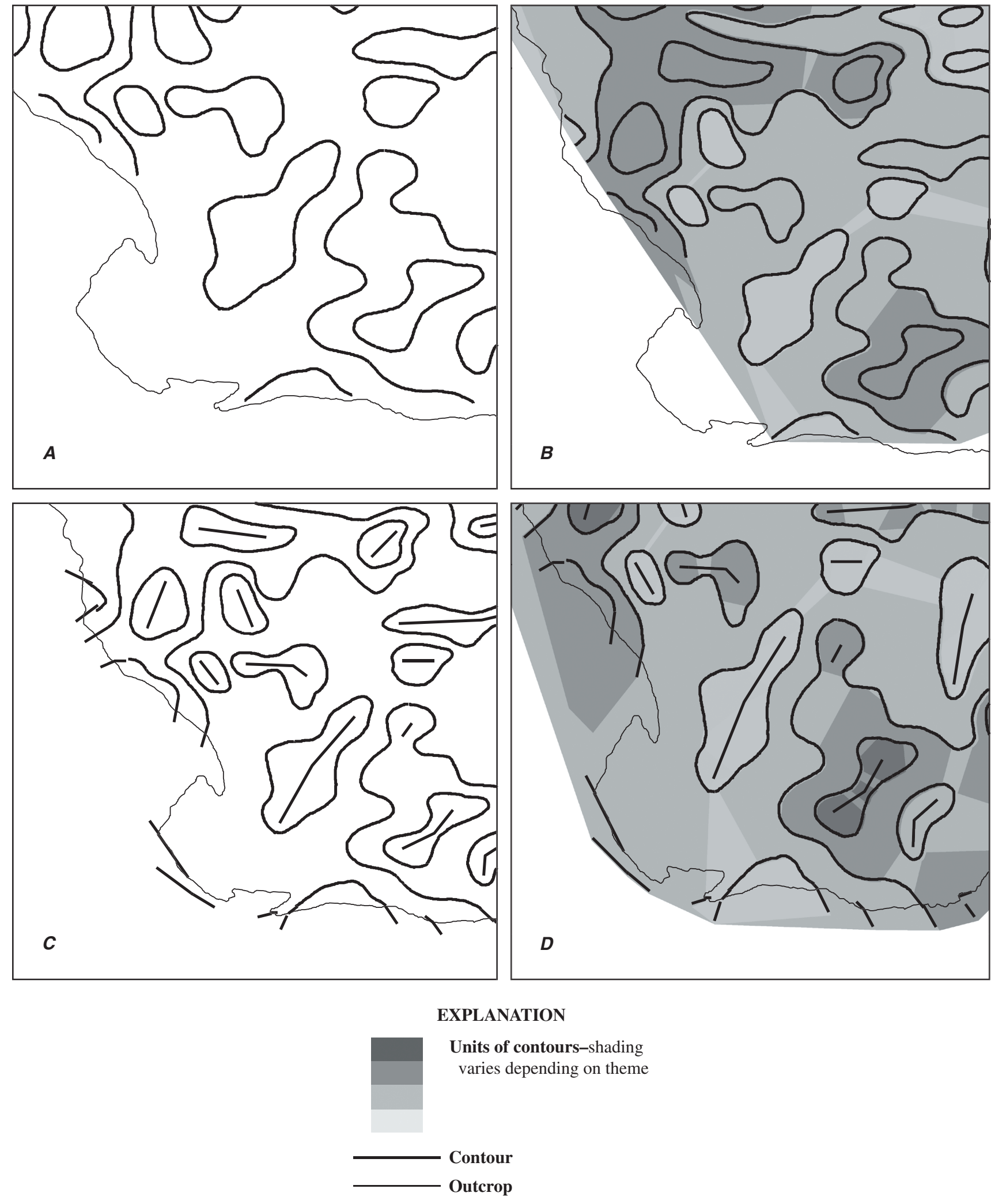

Figure 4. Example contours, outcrop, and triangulated irregular networks (TINS). $A$, original contours from Lewis and Hotchkiss (1981), $B$, TINS based on original contours, $C$, original contours and contours extended and added by manual methods, and $D$, revised TINS based on extended and added contours. 
change sign as one continued from the inflection point or line to the other known contour. In other words, the inflection point or line represents the crest of a hill or an arch, or the lowest point in a valley or a depression. In these areas, a line was added by manual methods and assigned a value (fig. 4C). The resulting TIN uses values from this line, and the area inside the closed contour (or between the contour ridge or trough) no longer has uniform values. Although values assigned to these lines were subjective, an analysis based on the resulting values is "less incorrect" than an analysis based on uniform values between contours. The result is "less incorrect" because the added line adds values that agree with an interpretation of a curved high (or low) instead of a flat plateau inside the closed contour (or between the contour ridge or trough). Values were selected to be consistent with contour intervals or the available data outside the high or low. An analysis of the possible error introduced by this method is described in the Sensitivity Analysis Methods section, and shows that any error due to this procedure is minor compared to other possible errors.

\section{Computation of Ground-Water Volumes}

The computation of volume of water in storage is illustrated with a hypothetical schematic of the basin (fig. 5). This schematic shows three of the six hydrogeologic units as nested bowls, with the bowl in the center of the basin, labeled as Tongue River-Wasatch aquifer, as the uppermost unit. The hydrogeologic units increase in age with depth and outward from the center of the basin. This schematic shows the water table not intersecting the land surface; however, areas may exist in the basin where this may happen. At any location, the saturated thickness for the Tongue River-Wasatch aquifer is given by $a$, which is the distance between the water table and the base of the Tongue River-Wasatch aquifer. The saturated thickness for the next lowest units, part of the Fort Union Formation, is more complicated. In areas where the potentiometric surface of Tullock aquifer is above the base of the Tongue River-Wasatch aquifer, the Tullock aquifer is confined and the saturated thickness of the Tullock aquifer, $b$, also is the apparent thickness of the Tullock aquifer. With increasing distance from the center of the basin, an area is reached where the water table is below the contact between the Tongue River-Wasatch aquifer and the Lebo Confining Unit $(B)$. In this area $(B)$, the Tongue River-Wasatch aquifer is completely unsaturated or absent. The amount of saturated thickness, $c$, is the difference between the water table and the base of the Tullock aquifer.

The transition of aquifers between confined and unconfined conditions is poorly understood. On figure 5, the Tullock aquifer is confined at $b$. Applied Hydrology and Greystone Environmental Consultants, Inc. (2002, Appendix B) report that aquifer test results in alluvial sediments, which are part of the Tongue River-Wasatch aquifer as described in this report, indicate that at some depth even these materials act in a confined manner. In this study, an assumption was made that when a hydrogeologic unit has more than 50 feet of saturated thickness, it is confined. Thus, specific yield was used as the storage factor for a saturated thickness of 50 feet or less, and specific storage was used as the storage factor for a saturated thickness greater than 50 feet.

Water-table data were from Hotchkiss and Levings (1986). The water table in the center of the basin (A in fig. 5) is from the approximate potentiometric surface in the Tongue River-Wasatch aquifer, whereas the water table (B in fig. 5) in stratigraphically lower units, represented by the Tullock aquifer in figure 5, is from potentiometric surface maps of other hydrogeologic units used in this report and given in Hotchkiss and Levings (1986).

In some areas of the study, potentiometric contours of Hotchkiss and Levings (1986) did not extend to the edge of the outcrop. In these areas, water levels in shallow wells were obtained from the USGS Ground-Water Site Inventory database and a point coverage was made of these water levels. A TIN was assembled from this coverage. This was done only in areas where contoured water levels of Hotchkiss and Levings (1986) were not available.

Any perched water-table zones were ignored in the calculation of ground-water volumes. The assumption was made that the extent of perched zones is small when compared to the entire area of the basin.

For all volume estimates of saturated rock using the first method to estimate ground-water volume, the total volume of water was calculated by summing a component of water in sands and a component of water in non-sands. For the unconfined part of the aquifers, equation 1 was used to calculate the total amount of water in the sands:

sandwater $=1,000 * 1,000 *($ sattk $*(\%$ sand $/ 100) *$ sand-porosity $)$

where:

sandwater $=$ the total amount of water in the sands, in cubic feet, $1,000 * 1,000=$ the area of the grid cell, in square feet,

sattk $=$ the saturated thickness $(a$ in figure 5), in feet,

$\%$ sand $=$ the percentage of sand, and

sand-porosity $=$ the porosity of the sand.

Equation 2 was used to calculate the total amount of water in the non-sand part of the cell:

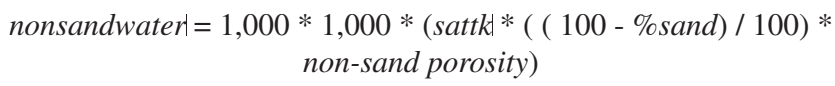

where:

nonsandwater $=$ the total amount of water in the non-sand component of the cell, in cubic feet,

$1,000 * 1,000=$ the area of the grid cell, in square feet,

$s a t t k=$ the saturated thickness $(a$ in figure 5), in feet,

$\%$ sand $=$ the percentage of sand, and

non-sand porosity $=$ the porosity of the non-sand component. 


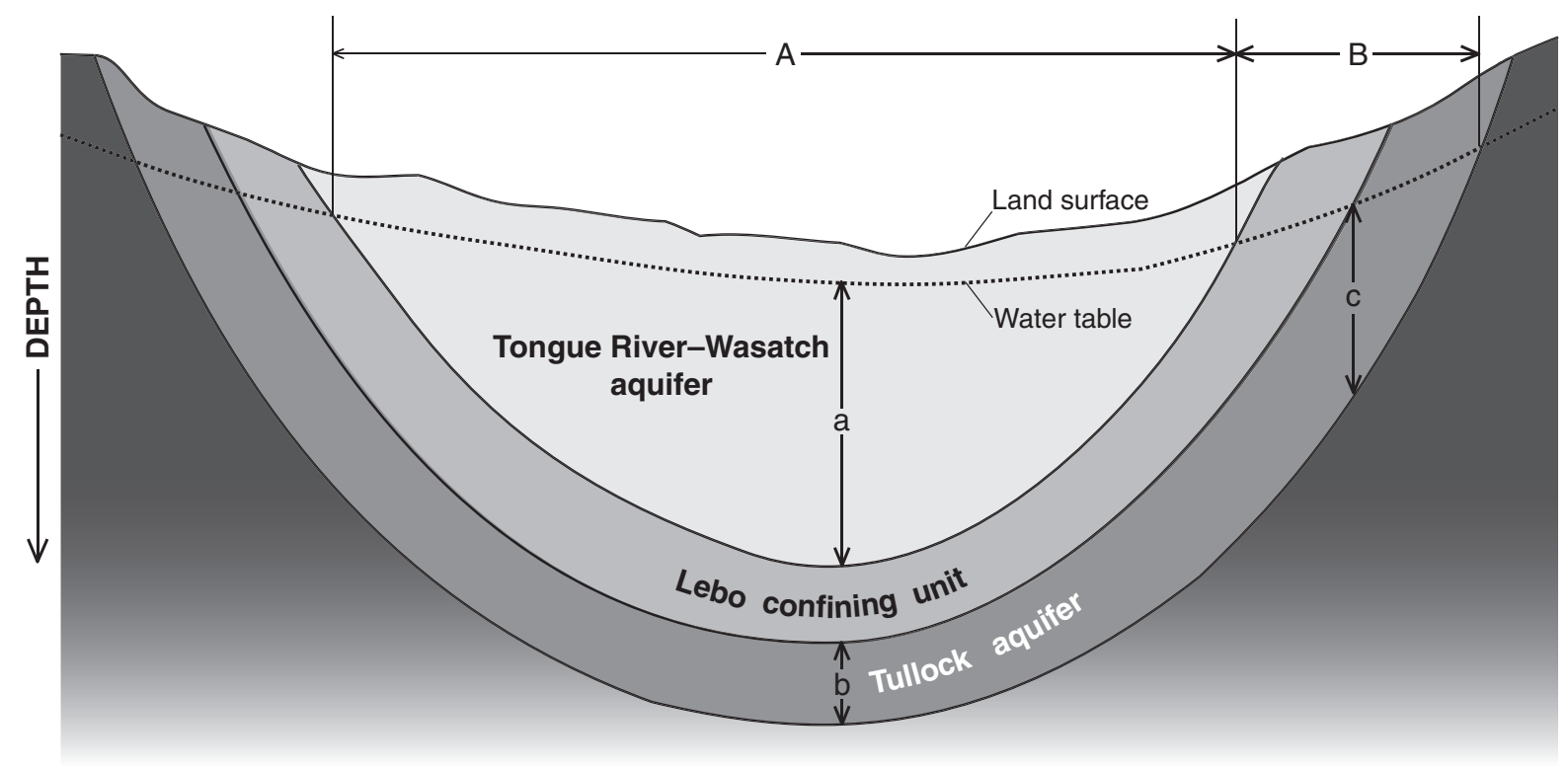

EXPLANATION

$A=$ area with water table in the Tongue River-Wasatch aquifer (from Hotchkiss and Levings, 1986)

$B=$ area with water table based on the Tullock aquifer (from Hotchkiss and Levings, 1986)

$\mathrm{a}=$ saturated thickness of the Tongue River-Wasatch aquifer

$\mathrm{b}=$ saturated thickness of the Tullock aquifer (confined)

c = saturated thickness of the Tullock aquifer (unconfined)

Figure 5. Schematic showing relations among land surface, water table, hydrogeologic units, and saturated section of the hydrogeologic units in the study area, Powder River structural basin, Wyoming.

Significant figures limit the number of meaningful digits in calculations. Common practice is to limit the number of significant figures in a mathematical operation to the number of significant figures in the least precise number (Hansen, 1991). For these calculations, the least precise numbers are porosity and percent sand in each of the units, which are given to two digits.

For hydrogeologic units below the Tongue River-Wasatch aquifer, similar formulas were used to calculate the volume of water, with special attention paid to the saturated thickness at each cell point. Conceptually, in areas where the unit is confined, the saturated thickness is given as the apparent thickness of the hydrogeologic unit, such as $b$ in figure 5. With proximity to the edge of the basin, the saturated thickness transitions from that shown in $b$ in figure 5 to the saturated thickness shown as $c$ in figure 5, which is where the water table in the hydrogeologic unit is the top boundary of the saturated thickness of that unit. Transitioning from the conceptual idealization to the practical implementation required careful consideration of selection criteria when designing the GIS procedure to carry out this task.

A second method to estimate ground-water volumes is to consider specific yield and specific storage in the calculations. For the unconfined part of the aquifers, the volume of water that could be recovered was calculated by multiplying the saturated thickness of the aquifer by the specific yield and the area of the grid cell. For confined parts of the aquifers, an assumption was made that only water in the saturated thickness of the Tongue River-Wasatch aquifer would be removed by pumping. For example, equation 3 was used to calculate the amount of water released from confined storage in the sand part of the Fox Hills-Lower Hell Creek aquifer if only the Tongue River-Wasatch aquifer is dewatered:

$$
s f h v s=1,000 * 1,000 *(\text { fhtk } *(\text { fhsnd / 100 }) * S s n d) *(\text { trwsattk })
$$

where:

$s f h v s=$ the volume of water released from confined storage in the sand part of the Fox Hills-Lower Hell Creek aquifer, in cubic feet, $1,000 * 1,000=$ the area of the grid cell, in square feet,

fhtk $=$ the confined thickness of the Fox Hills-Lower Hell Creek aquifer, in feet,

fhsnd $=$ the percentage of sand in the Fox Hills-Lower Hell Creek aquifer,

Ssnd $=$ specific storage for sand, in feet ${ }^{-1}$, and

trwsattk $=$ the saturated thickness in the Tongue River-Wasatch aquifer, in feet.

The procedure using equation 3 for the Fox Hills-Lower Hell Creek aquifer was repeated for each hydrogeologic unit. Estimated ground-water volumes were determined for the sand 
and non-sand parts of each unit using appropriate values of confined thickness, percentage sand, and specific storage.

Toward the edge of the basin, the Tongue River-Wasatch aquifer is not present (fig. 3). In these areas, the saturated thickness of the outcropping unit was assumed to be pumped dry and the change in head relative to the base of the outcropping unit was used to calculate the amount of water released from storage from each hydrogeologic unit underlying the outcropping unit. Thus, if the Lebo confining unit was the outcropping unit, then the water released from the Tullock aquifer, the Upper Hell Creek confining unit, and the Fox Hills-Lower Hell Creek aquifer was calculated by using the saturated thickness of the Lebo confining unit as the change in hydraulic head in the lower units. Toward the outer edge of the basin, older units became the outcropping units and the procedure just described was repeated.

\section{Sensitivity Analysis Methods}

Estimates of error can be highly theoretical; for example, see articles in Mower and Congalton (2000) and Lowell and Jaton (1999). A sensitivity analysis was conducted on selected factors used to calculate the ground-water volume by use of porosity and by recording how sensitive the ground-water volume estimates were to these selected factors. Although some hydrogeologic parameters are only known to within an order of magnitude difference, for this analysis, an error of 10 percent was used for most parameters. For example, if the thickness of a unit was $300 \mathrm{ft}$, then a value of $330 \mathrm{ft}$ was used in the analysis, or if the porosity was 30 percent, then a value of 33 percent was used in the analysis. These values were then plotted in a graph to show how sensitive the volume of ground water was to these factors.

Two types of errors were studied for factors that were based on contour maps. The first type of possible error is a systematic error in all of the values. Figure 6 shows how this error was evaluated. Figure 6A shows a group of contours with original values. Figure 6B shows each of these contours with each value increased by 10 percent. These contours were then used to make a TIN that was sampled, and the sampled values were used to calculate a ground-water volume, which was then compared to a base value of ground-water volume. The difference between these two volumes was calculated and differences were compiled to determine the sensitivities of possible systematic errors.

The second type of possible error is from the values of the extended or added inflection lines. As discussed previously, inflection lines occur between contours that have the same values. The values selected for these inflection lines were subjective and were the focus of this analysis. Figure 7A shows the inflection line with a value of 62 , which was assigned by the author. What if another value had been used? Figure 7B shows that the value of the inflection line was increased about 10 percent to 68 . In this analysis, all of the inflection lines of a theme were varied in a similar man- 

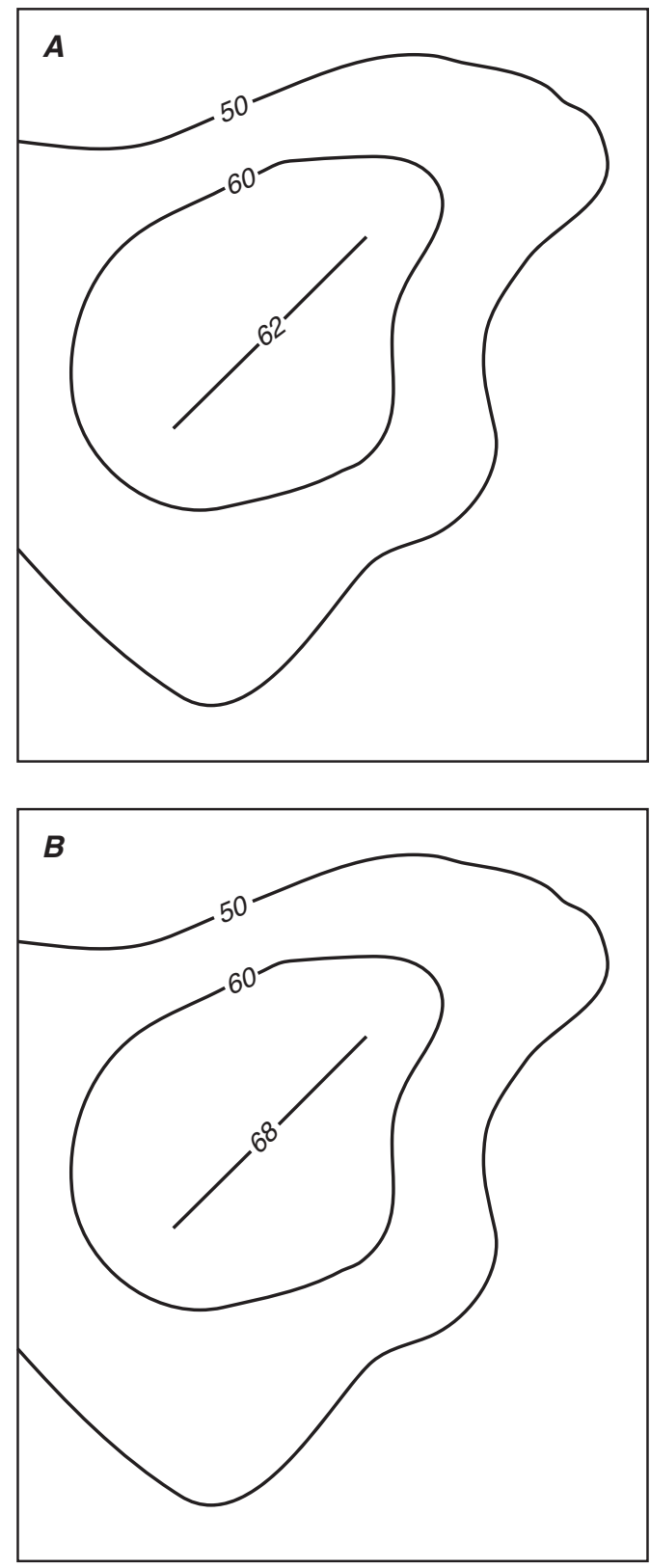

Figure 7. Sketch showing how the values of inflection lines were changed in the center of the closed contour, with the value used in the base analysis $(A)$, and showing the changed value of the inflection line $(B)$, which was used in the sensitivity analysis. ner, then the theme was used to make a TIN of that modified theme. This TIN was sampled and the sampled values were used to calculate a ground-water volume, which was then compared to the base ground-water volume. The difference between these two volumes was calculated, which was used as a measure of the sensitivity of the values of the inflection lines.

\section{Estimates of Ground-Water Volumes}

Two different calculations were used to estimate groundwater volumes in Tertiary and upper Cretaceous hydrogeologic units in the Powder River Basin in Wyoming. The first method used the porosity of the units and the second method used specific yield and specific storage. Both calculations gave results for unconfined and confined parts of each hydrogeologic unit.

\section{Hydraulic Properties Used in Estimating Ground-Water Volumes}

Regional compilations of porosity are not available for the hydrogeologic units of interest in this study. Literature values were used to obtain approximate porosity values for both sand and non-sand parts of the hydrogeologic units. Textbooks give varying ranges of possible porosities. Freeze and Cherry (1979) give ranges for sand and non-sand porosities of 25 to 50 percent and 25 to 70 percent, respectively, with higher values for clays and lower values for gravels. Fetter (1988) reports that porosities in clastic rocks can range from 3 to 30 percent. Domenico and Schwartz (1990) report sand porosities that range from 26 to 53 percent and non-sand porosities that range from 24 to 60 percent, with higher porosities found in silts and clays. In this study, the following porosities were assumed: sand porosity of 30 percent and non-sand porosity of 35 percent (table 1$)$.

Storage parameters from a compilation of aquifer tests for the upper hydrogeologic section of the Powder River Basin (see Appendix B of Applied Hydrology Associates, Inc. and Greystone Environmental Consultants, Inc., 2002) are consistent with the hydrogeologic setting of the sediments. Specific yield values from textbooks (Fetter, 1988; Domenico and Schwartz, 1990) refer to work by Johnson (1967) and range from 3 percent for clay to 27 percent for sandstones, with higher values for lithologies that are not reported to be in the Powder River Basin. In this study, specific yields of 26 percent for sand and 10 percent for non-sand were used, and specific storages of $1 \times 10^{-4} / \mathrm{ft}$ for sand and $1 \times 10^{-5} / \mathrm{ft}$ for non-sand were used (table 1). 
Table 1. Hydraulic properties of hydrogeologic units in the Powder River Basin used to estimate groundwater volumes.

\begin{tabular}{llccl}
\hline \multicolumn{1}{c}{ Hydrogeologic unit } & Lithology & $\begin{array}{c}\text { Porosity, } \\
\text { in percent }\end{array}$ & $\begin{array}{c}\text { Specific yield, } \\
\text { in percent }\end{array}$ & $\begin{array}{c}\text { Specific storage } \\
\text { (1/feet) }\end{array}$ \\
\hline Tongue River-Wasatch aquifer & Sand & 30 & 26 & $1 \times 10^{-4}$ \\
& Non-sand & 35 & 10 & $1 \times 10^{-5}$ \\
Lebo confining unit & Sand & 30 & 26 & $1 \times 10^{-4}$ \\
& Non-sand & 35 & 10 & $1 \times 10^{-5}$ \\
Tullock aquifer & Sand & 30 & 26 & $1 \times 10^{-4}$ \\
& Non-sand & 35 & 10 & $1 \times 10^{-5}$ \\
Upper Hell Creek confining layer & Sand & 30 & 26 & $1 \times 10^{-4}$ \\
& Non-Sand & 35 & 10 & $1 \times 10^{-5}$ \\
Fox Hills-Lower Hell Creek aquifer & Sand & 30 & 26 & $1 \times 10^{-4}$ \\
& Non-sand & 35 & 10 & $1 \times 10^{-5}$ \\
\hline
\end{tabular}

\section{Ground-Water Volumes Derived from Porosity}

For total ground-water volumes calculated using porosity values (table 2), the confined part of the aquifers contain much more water than the unconfined part of the aquifers. This is due to the difference in volume of rock between the confined and unconfined parts. The unconfined part of the aquifers was assumed to be only the upper 50 feet of the stratigraphic section. Under this thin veneer of unconfined conditions may be thousands of feet of rock containing water under confined conditions (fig. 3). However, much of this water is not available for two reasons. First, for fine-grained sediments, it is difficult to pump this water out of these sediments because of their low permeability. Second, some of the water is interstitial wetting fluid, and thus unrecoverable.

\section{Ground-Water Volumes Derived from Specific Yield and Specific Storage}

For the recoverable ground-water volumes derived from specific yield and specific storage calculations (table 3), the non-sand part of hydrogeologic units contains less water than the sand part of hydrogeologic units. For the unconfined part of the aquifers, the non-sand facies contain about 40-65 percent less water than the sand facies, and for the confined part of the aquifers, the non-sand facies contain 80-90 percent less water than the sand facies. The unconfined part of the Tongue River-Wasatch aquifer has more water than the confined part of the same aquifer. For all of the other hydrogeologic units, the confined part of the aquifers contains more water than the unconfined part.
Water volumes calculated using specific yield and specific storage are less than water volumes calculated using porosity. This relation follows from the fact that specific yield is equal to porosity minus specific retention (Lohman and others, 1972). Specific retention is moisture bound to the surfaces of particles and this moisture does not drain by gravity. For confined aquifers, the storage coefficient is the volume of water an aquifer releases from storage per unit surface area of the aquifer per unit change in head (Lohman and others, 1972).

The following comparisons help place ground-water volume into a "real-world" context. The total ground-water volume estimated from storativity $\left(3.6 \times 10^{13} \mathrm{ft}^{3}\right)$ is less water than is held in Lake Ontario but more than twice the water held in Lake Erie (lake water volumes from U.S. Environmental Protection Agency, 2004).

\section{Sensitivity Analysis}

A sensitivity analysis of selected factors shows that ground-water volume is most sensitive to changes in porosity of sand and non-sand facies (table 4, figure 8). The next two most sensitive factors are confined thickness and saturated thickness. Ground-water volume is not very sensitive to the sand percentage, and ground-water volume has very low sensitivity to values applied to inflection lines used in making the TIN of the sand percentage.

The sensitivity analysis also provides an indication of uncertainty for the calculated ground-water volumes. This analysis varied porosity by 10 percent, so that 30 percent porosity became 33 percent and 35 percent porosity became 38.5 percent. Because of the communicative nature of porosity in the calculation, a 10 percent change in porosity resulted 
Table 2. Estimated ground-water volumes in Tertiary and upper Cretaceous hydrogeologic units in the Powder River Basin based on porosity.

\begin{tabular}{|c|c|c|c|}
\hline \multirow[b]{2}{*}{ Hydrogeologic Unit } & \multicolumn{3}{|c|}{ Volume of ground water in facies (cubic feet) } \\
\hline & Sand & Non-sand & Total \\
\hline \multicolumn{4}{|c|}{ Unconfined (for saturated thickness less than or equal to 50 feet) } \\
\hline Tongue River-Wasatch aquifer & $1.7 \times 10^{12}$ & $1.8 \times 10^{12}$ & $3.5 \times 10^{12}$ \\
\hline Lebo confining unit & $3.1 \times 10^{11}$ & $4.7 \times 10^{11}$ & $7.8 \times 10^{11}$ \\
\hline Tullock aquifer & $1.7 \times 10^{12}$ & $1.8 \times 10^{12}$ & $3.5 \times 10^{12}$ \\
\hline Upper Hell Creek confining layer & $1.5 \times 10^{11}$ & $2.9 \times 10^{11}$ & $4.4 \times 10^{11}$ \\
\hline Fox Hills-Lower Hell Creek aquifer & $2.7 \times 10^{11}$ & $3.7 \times 10^{11}$ & $6.4 \times 10^{11}$ \\
\hline Total for unconfined units & $4.1 \times 10^{12}$ & $4.8 \times 10^{12}$ & $8.9 \times 10^{12}$ \\
\hline \multicolumn{4}{|c|}{ Confined (for saturated thickness greater than 50 feet) } \\
\hline Tongue River-Wasatch aquifer & $5.6 \times 10^{13}$ & $6.7 \times 10^{13}$ & $1.2 \times 10^{14}$ \\
\hline Lebo confining unit & $1.6 \times 10^{13}$ & $9.1 \times 10^{12}$ & $2.4 \times 10^{13}$ \\
\hline Tullock aquifer & $1.6 \times 10^{13}$ & $6.5 \times 10^{12}$ & $2.2 \times 10^{13}$ \\
\hline Upper Hell Creek confining layer & $4.3 \times 10^{12}$ & $4.5 \times 10^{12}$ & $8.9 \times 10^{12}$ \\
\hline Fox Hills-Lower Hell Creek aquifer & $7.8 \times 10^{12}$ & $6.6 \times 10^{12}$ & $1.5 \times 10^{13}$ \\
\hline Total for confined units & $9.9 \times 10^{13}$ & $9.4 \times 10^{13}$ & $1.9 \times 10^{14}$ \\
\hline Total for confined and unconfined units & $1.0 \times 10^{14}$ & $9.9 \times 10^{13}$ & $2.0 \times 10^{14}$ \\
\hline
\end{tabular}

in about a 10 percent change in ground-water volume. The 30 percent and 35 percent porosity values used in the calculations could have easily been justified as 25 percent and 40 percent or some other values with the corresponding change in calculated volume. Without having detailed maps of field-derived porosity values for the hydrogeologic units, it is difficult to quantify the uncertainty of the porosity values used. Although representative values were used in the calculations given in this report, the values used are certainly not the only values that could have been used. If one assumed an uncertainty in porosity of 33 percent, then the uncertainty of the calculated ground-water volumes also is about 33 percent. Given this possible uncertainty, readers should consider the groundwater volumes given in this report as order of magnitude ground-water volumes and not as exact ground-water volumes. Thus, in this report, the results are referred to as estimates.

\section{Comparison with a Previous Study}

The purpose of this section is to compare the results of this study with the results from a previous study. Applied Hydrology Associates, Inc. and Greystone Environmental Consultants, Inc. (2002) made an estimate of available water from units associated with CBM development. The estimates of ground water for the sandstones can be compared to estimates given in this report of ground-water volumes for sand units that are based on storativity factors.

For the sandstones of the Tongue River-Wasatch aquifer, there is about an order of magnitude difference in water volumes calculated by the two studies (table 5). For the sandstones in the Lebo confining unit and the Tullock aquifer, the agreement between the two studies is much better. These variations in results from the two studies demonstrate the uncertainty in estimates calculated by using available data. 
Table 3. Estimated ground-water volumes in Tertiary and upper Cretaceous hydrogeologic units in the Powder River Basin based on specific yield and specific storage.

\begin{tabular}{llll}
\hline & \multicolumn{2}{c}{ Volume of ground water in facies (cubic feet) } \\
\cline { 2 - 3 } Hydrogeologic unit & \multicolumn{1}{c}{ Sand } & \multicolumn{1}{c}{ Non-sand } & Total \\
\hline \multicolumn{1}{c}{ Unconfined (for saturated thickness less than or equal to 50 feet) } & \\
\hline Tongue River-Wasatch aquifer & $1.4 \times 10^{12}$ & $5.3 \times 10^{11}$ & $2.0 \times 10^{12}$ \\
Lebo confining unit & $2.7 \times 10^{11}$ & $1.3 \times 10^{11}$ & $4.0 \times 10^{11}$ \\
Tullock aquifer & $2.5 \times 10^{11}$ & $1.2 \times 10^{11}$ & $3.7 \times 10^{11}$ \\
Upper Hell Creek confining layer & $1.3 \times 10^{11}$ & $8.2 \times 10^{10}$ & $2.1 \times 10^{11}$ \\
Fox Hills-Lower Hell Creek aquifer & $2.4 \times 10^{11}$ & $1.0 \times 10^{11}$ & $3.4 \times 10^{11}$ \\
Total for unconfined units & $\mathbf{2 . 3 \times 1 0 ^ { 1 2 }}$ & $\mathbf{9 . 7} \times \mathbf{1 0}$ & $\mathbf{3 . 3 \times 1 0 ^ { 1 2 }}$ \\
\hline \multicolumn{1}{c}{ Confined (for saturated thickness greater than } & $50 \mathrm{feet}$ ) & \\
\hline Tongue River-Wasatch aquifer & $1.9 \times 10^{10}$ & $1.9 \times 10^{9}$ & $2.0 \times 10^{10}$ \\
Lebo confining unit & $1.1 \times 10^{13}$ & $2.2 \times 10^{12}$ & $1.3 \times 10^{13}$ \\
Tullock aquifer & $1.2 \times 10^{13}$ & $1.2 \times 10^{12}$ & $1.3 \times 10^{13}$ \\
Upper Hell Creek confining layer & $2.1 \times 10^{12}$ & $3.9 \times 10^{11}$ & $2.5 \times 10^{12}$ \\
Fox Hills-Lower Hell Creek aquifer & $3.4 \times 10^{12}$ & $4.1 \times 10^{11}$ & $3.9 \times 10^{12}$ \\
Total for confined units & $\mathbf{2 . 8 \times 1 0 ^ { 1 3 }}$ & $\mathbf{4 . 2 \times 1 0 ^ { 1 2 }}$ & $\mathbf{3 . 2 \times 1 0 ^ { 1 3 }}$ \\
\hline Total for unconfined and confined units & $\mathbf{3 . 0 \times 1 0 ^ { 1 3 }}$ & $\mathbf{5 . 2 \times 1 0 ^ { 1 2 }}$ & $\mathbf{3 . 6 \times 1 0 ^ { 1 3 }}$ \\
\hline
\end{tabular}

Table 4. Sensitivity of calculated ground-water volumes to selected factors used to calculate the ground-water volumes.

\begin{tabular}{|c|c|c|c|}
\hline Volume factor & $\begin{array}{l}\text { Total ground-water volume with changed } \\
\text { parameter minus base total ground-water } \\
\text { volume }{ }^{\mathrm{a}} \text {, in cubic feet }\end{array}$ & Percent error ${ }^{b}$ & $\begin{array}{c}\text { Sensitivity } \\
\text { (unitless) }\end{array}$ \\
\hline Sand and non-sand porosity & $-4.5 \times 10^{13}$ & -22.5 & 2.25 \\
\hline Confined thickness & $-2.5 \times 10^{13}$ & -12.5 & 1.25 \\
\hline Saturated thickness & $-1.7 \times 10^{13}$ & -8.5 & 0.85 \\
\hline Percentage sand & $2.9 \times 10^{12}$ & 1.45 & 0.15 \\
\hline $\begin{array}{l}\text { Values used for inflection lines in the } \\
\text { sand porosity coverage }\end{array}$ & $1.84 \times 10^{10}$ & $0.01^{\mathrm{b}}$ & 0.001 \\
\hline
\end{tabular}

aBase total ground-water volume from table 2 is $2 \times 10^{14}$ cubic feet.

${ }^{\mathrm{b}}$ Calculated as $100 \mathrm{x}$ (total ground-water volume with changed parameter - base total ground-water volume) / base total ground-water volume.

'Calculated as absolute value of percent error / 10.

${ }^{\mathrm{d}} \mathrm{See}$ the discussion associated with figure 7 for a more complete discussion of this factor. 


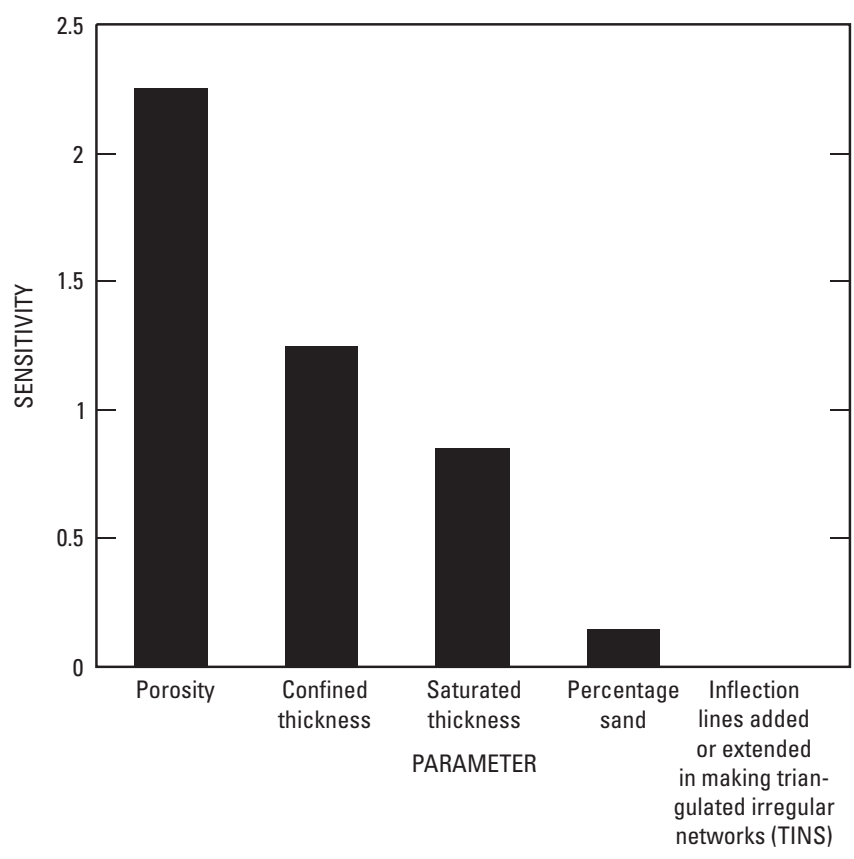

Figure 8. Sensitivity of calculated ground-water volumes to selected factors used to calculate ground-water volumes.

\section{Discussion of Ground-Water Volumes}

When considering ground-water volumes estimated in this report, the distinction between total water and recoverable water must be understood. Volume estimates from porosity are the total volume of water that these facies may hold and not the actual amount of water that is available if an attempt was made to remove all water from these hydrogeologic units. Volume estimates from the storativity factors are the amount of water that could be pumped given considerable dewatering of the basin. Thus, both estimates given in this report represent the extreme upper bounds, with the former a bound on the maximum amount of water in the basin and the latter a bound on the maximum amount of water that could be produced.

Several factors were not included in this analysis, mainly due to time constraints and the scope of this study. Two of these factors are the thickness of coals and clinker zones. Several compilations of coal thickness are available, but those of the Wyoming State Geological Survey (James Case, oral commun., 2003) were not completed when work for this project was completed, and they do not cover the whole of the Wyoming part of the Powder River Basin. A map by Ellis and others (1999) provides the thickness for one of the coal zones in the Tongue River Member of the Fort Union Formation but not the total thickness of all coal zones. Clinker zones, which are areas of coals that have burned, have a smaller extent than coal zones and have few zones of fairly high porosity and specific yield (Coates and Heffern, 1999; Heffern and Coates, 1999).

Significant figures limit the number of digits reported for estimates of ground-water volumes. Porosity and the thickness of sands are known only to two significant figures. Providing numbers with more than two significant digits only gives the reader an unfounded sense of the precision of the results.

Table 5. Comparison of estimates of available volumes of ground water from Applied Hydrology Associates, Inc. and Greystone Environmental Consultants, Inc. (2002) to the estimates of ground-water volumes determined in this study from storativity factors.

[AHA, Applied Hydrology Associates, Inc. and Greystone Environmental Consultants, Inc., estimates of water volume; $\mathrm{ft}^{3}$, cubic feet; 1 acre-foot $\left.=43,560 \mathrm{ft}^{3}\right]$

\begin{tabular}{|c|c|c|c|c|c|c|c|}
\hline & \multicolumn{2}{|c|}{ Volume from AHA study } & \multicolumn{3}{|c|}{ Volume from this study } & \multirow{2}{*}{$\begin{array}{l}\text { Difference } \\
\text { between } \\
\text { studies }\left(\mathrm{ft}^{3}\right)\end{array}$} & \multirow[b]{2}{*}{$\begin{array}{l}\text { Percent } \\
\text { difference }\end{array}$} \\
\hline & Acre-feet & Cubic $\mathrm{ft}^{3}$ & $\begin{array}{l}\text { Unconfined } \\
\qquad\left(\mathrm{ft}^{3}\right)\end{array}$ & $\begin{array}{l}\text { Confined } \\
\left(\mathrm{ft}^{3}\right)\end{array}$ & Total $\left(\mathrm{ft}^{3}\right)$ & & \\
\hline $\begin{array}{l}\text { Tongue River-Wasatch } \\
\text { sandstones }\end{array}$ & $743,121,790$ & $3.2 \times 10^{13}$ & $1.4 \times 10^{12}$ & $1.9 \times 10^{10}$ & $1.4 \times 10^{12}$ & $3.1 \times 10^{13}$ & 96 \\
\hline Lebo sandstones & $227,137,336$ & $9.9 \times 10^{12}$ & $2.7 \times 10^{11}$ & $1.1 \times 10^{13}$ & $1.1 \times 10^{13}$ & $-1.4 \times 10^{12}$ & -14 \\
\hline Tullock sandstones & $447,246,784$ & $2.0 \times 10^{13}$ & $2.5 \times 10^{11}$ & $1.2 \times 10^{13}$ & $1.2 \times 10^{13}$ & $7.8 \times 10^{12}$ & 39 \\
\hline
\end{tabular}

'Percent difference as used in this table is calculated as $\frac{a-b}{b}$, where $a$ is "volume from AHA study" in $\mathrm{ft}^{3}$, and $b$ is "volume from this study" in $\mathrm{ft}^{3}$. 


\section{Approaches to Increase Accuracy of Ground-Water Volume Estimates}

The estimates of ground-water volumes in Tertiary and upper Cretaceous hydrogeologic units presented in this report could be refined if additional information was available. Although the collection and compilation of this information was beyond the scope of this study at least five approaches are available to obtain information that might increase the accuracy of ground-water volume estimates made in this report. They include (1) compilation of basin-wide maps of the tops and bottoms of coals, or maps of coal thickness, (2) compilation of basin-wide maps of storage factors for the hydrogeologic units, (3) compilation of basin-wide maps of porosity for the hydrogeologic units, (4) compilation of water-table maps either synoptically or temporally, and (5) inclusion of clinker zones in the analysis.

Compilation of basin-wide coal thickness maps is important; however, the extent of any given coal in the basin is often contentious, and gaining consensus among the many coal geologists practicing in the basin is needed. The advantage to this approach is that coal properties, including low storativity, fracturing, high hydraulic conductivities, and their lateral extent, would add greatly to future hydrogeologic and geologic studies, including revised estimates of ground-water volumes.

After coal thickness, knowing the distribution of porosity in the hydrogeologic units of interest would likely have the most effect on improving ground-water volume estimates. Porosity has been shown to have the most effect on these estimates, and detailed information about porosity distribution in the Powder River Basin is available in the public literature. Porosity is important not only in estimating ground-water volume, but also for simulation of ground-water flow, solute transport, and ground-water chemistry.

Basin-wide maps of storage factors would provide insight about where aquifers transit from unconfined to confined conditions. Storage factors could be correlated with local lithology to extend knowledge of relations in this area.

Water-table maps, either synoptic or temporal, would improve knowledge about the saturated thickness of the hydrogeologic units of interest, which directly relates to ground-water volume. These maps would help determine how ground-water volume changes, both seasonally and over long periods of time.

Finally, the addition of clinker zones to the analysis would add limited areas of high porosity and high specific yield. However, due to the limited extent of clinker zones, their contribution to estimates of ground-water volume might be minimal. Until such an analysis is undertaken, this assumption cannot be validated.

\section{Summary}

The Powder River Basin in Wyoming and Montana is an important source of energy resources for the United States. Coalbed methane gas is contained in Tertiary and upper Cretaceous hydrogeologic units in the Powder River Basin. This gas is released when water pressure in coalbeds is lowered, usually by pumping ground water. Issues related to disposal and uses of by-product water from coalbed methane production have developed, in part, due to uncertainties in hydrologic properties. One hydrologic property of primary interest is the amount of water contained in Tertiary and upper Cretaceous hydrogeologic units in the Powder River Basin. The U.S. Geological Survey, in cooperation with the Bureau of Land Management, conducted a study to describe the hydrogeologic framework and to estimate ground-water volumes in Tertiary and upper Cretaceous hydrogeologic units in the Powder River Basin in Wyoming.

The Tertiary and upper Cretaceous hydrogeologic units of interest for this study are (in descending order): Tongue River-Wasatch aquifer, which is contained in the Eocene-age Wasatch Formation and the Paleocene-age Fort Union Formation; the Lebo confining unit, which is contained in the upper part of the Lebo Shale Member of the Fort Union Formation; the Tullock aquifer, which is contained in the lower part of the Lebo Shale Member and in the Tullock Member of the Fort Union Formation; the Upper Hell Creek confining layer, which is contained in the upper part of the upper Cretaceousage Lance Formation; and the Fox Hills-Lower Hell Creek aquifer, which is contained in the lower part of the Lance Formation and the upper Cretaceous-age Fox Hills Sandstone. All of these hydrogeologic units contain varying amounts of sand and non-sand facies.

Maps from previous investigations, including altitudes of potentiometric surfaces, altitudes of formation tops and bottoms, thicknesses, and percentages of sand, were used in developing a geographic information system to estimate the volume of ground water in the hydrogeologic units of interest. Literature porosity values of 30 percent for sand and 35 percent for non-sand facies were used to calculate the volume of total ground water in each hydrogeologic unit. Literature specific yield values of 26 percent for sand and 10 percent for non-sand facies, and literature specific storage values of $1 \times 10^{-4} / \mathrm{ft}$ for sand facies and $1 \times 10^{-5} / \mathrm{ft}$ for non-sand facies were used to calculate a second volume of total ground water for each hydrogeologic unit.

A total ground-water volume of $2.0 \times 10^{14}$ cubic feet was calculated using porosity values, and a total ground-water volume of $3.6 \times 10^{13}$ cubic feet was calculated using specific yield and specific storage values. These results are consistent with retention properties, which would have some of the total water being retained.

Sensitivity analysis shows that estimates of ground-water volume are most sensitive to porosity. Estimates also are sensitive to confined thickness and saturated thickness. Given 
the uncertainty associated with the estimates presented in this report, the ground-water volumes should be considered as order of magnitude estimates.

\section{References}

Applied Hydrology Associates, Inc. and Greystone Environmental Consultants, Inc., 2002, Groundwater modeling of impacts associated with mining coal bed methane development in the Powder River Basin in Technical Report Powder River Basin Oil and Gas Environmental Impact Statement: U.S. Bureau of Land Management, Buffalo Field Office, various pagination.

Ayers, W.B., Jr., 1986, Lacustrine and fluvial-deltaic depositional systems, Fort Union Formation (Paleocene), Powder River Basin, Wyoming and Montana: American Association of Petroleum Geologist Bulletin, v. 70, no. 11, p. 1651-1673.

Bartos, T.T., and Ogle, K.M., 2002, Water quality and environmental isotopic analyses of ground-water samples collected from the Wasatch and Fort Union Formations in areas of coalbed methane development-implications to recharge and ground-water flow, Eastern Powder River Basin, Wyoming: U.S. Geological Survey Water-Resources Investigations Report 02-4045, 88 p.

Brown, J.L., 1993, Sedimentology and depositional history of the lower Paleocene Tullock Member of the Fort Union Formation, Powder River Basin, Wyoming and Montana: U.S. Geological Survey Bulletin 1917-L, 42 p.

Coates, D.A., and Heffern, E.L., 1999, Origin and geomorphology of clinker in the Powder River Basin, Wyoming and Montana in Miller, W.R., ed., Coalbed methane and the Tertiary geology of the Powder River Basin, Wyoming and Montana: Wyoming Geological Association Guidebook, v. 50, p. 211-230.

Conner, C.W., 1992, The Lance Formation-petrography and stratigraphy, Powder River Basin and nearby basins, Wyoming and Montana: U.S. Geological Survey Bulletin 1917-I, $117 \mathrm{p}$.

Cooper, G.G., Cardinal, D.F., Lorenz, H.W., and Lynn, J.R., eds., 1963, Northern Powder River Basin, Wyoming and Montana Guidebook: First Joint Field Conference, Wyoming Geological Association and Billings Geological Society, 202 p.

Daddow, P.B., 1986, Potentiometric-surface map of the Wyodak-Anderson Coal Bed, Powder River Structural Basin, Wyoming, 1973-84: U.S. Geological Survey WaterResources Investigations Report 85-4305, 1 sheet, scale 1:250,000.
Diedrich, R.P., Dyka, M.A.K., and Miller, W.R., eds., 1988, Eastern Powder River Basin-Black Hills: Casper, Wyoming, Wyoming Geological Association Guidebook, 324 p.

Domenico, P.A., and Schwartz, F.W., 1990, Physical and Chemical Hydrogeology: New York, John Wiley \& Sons, $824 \mathrm{p}$.

Ellis, M.S., Gunther, G.L., Ochs, A.M., Roberts, S.B., Wilde, E.M., Schuenemeyer, J.H., Power, H.C., Stricker, G.D., and Blank, D., 1999, Coal Resources, Powder River Basin: U.S. Geological Survey Professional Paper 1625-A, Chapter PN, $32 \mathrm{p}$.

Fetter, C.W., 1988, Applied Hydrogeology, (2d ed.): Columbus, Ohio, Mervill Publishing Co., 592 p.

Flores, R.M., and Bader, L.R., 1999, Fort Union coal in the Powder River Basin, Wyoming and Montana-A synthesis: in U.S. Geological Survey Professional Paper 1625-A, Chapter PS, 49 p.

Flores, R.M., Ochs, A.M., Bader, L.R., Johnson, R.C., and Vogler, D., 1999, Framework geology of the Fort Union coal in the Powder River Basin: U.S. Geological Survey Professional Paper 1625-A, Chapter PF, 37 p.

Fort Union Coal Assessment Team, 1999, National Coal Resource Assessment, 1999 Resource assessment of selected Tertiary coal beds and zones in the Northern Rocky Mountains and Great Plains Region: U.S. Geological Survey Professional Paper 1625-A; CD-ROM disks 1 and 2, version 1.1.

Freeze, R.A. and Cherry, J.A., 1979, Groundwater: Englewood Cliffs, N.J., Prentice-Hall, 604 p.

Hansen, W.R., 1991, Suggestions to authors of the reports of the United States Geological Survey (7th ed.): U.S. Geological Survey, 289 p.

Heffern, E.L. and Coates, D.A., 1999, Hydrogeology and ecology of clinker in the Powder River Basin, Wyoming and Montana, in Miller, W.R., ed., Coalbed methane and the Tertiary geology of the Powder River Basin, Wyoming and Montana: Wyoming Geological Association Guidebook, v. 50 , p. $231-252$.

Hotchkiss, W.R., and Levings, J.F., 1986, Hydrogeology and simulation of water flow in strata above the Bearpaw Shale and equivalents of eastern Montana and northeastern Wyoming: U.S. Geological Survey Water-Resources Investigations Report 85-4281, 72 p.

Johnson, A.I., 1967, Specific yield-compilation of specific yields for various materials: U.S. Geological Survey WaterSupply Paper 1662-D, 74 p. 
Johnson, R.C., and Flores, R.M., 1998, Developmental geology of coalbed methane from shallow to deep in Rocky Mountain basins and in Cook Inlet-Matanuska basin, Alaska, U.S.A. and Canada: International Journal of Coal Geology, v. 35, p. 241-282.

Lewis, B.D., and Hotchkiss, W.R., 1981, Thickness, percent sand, and configuration of shallow hydrogeologic units in the Powder River Basin, Montana and Wyoming: U.S. Geological Survey Miscellaneous Investigations Series Map I-1317, scale 1:1,000,000, 6 sheets.

Lohman, S.W., and others, 1972, Definitions of selected ground-water terms-Revisions and conceptual refinements: U.S. Geological Survey Water-Supply Paper 1988, 21 p. (available online at URL http://water.usgs.gov/pubs/ wsp/wsp_1988/pdf/wsp_1988.pdf

Lowell, Kim, and Jaton, Annick, eds., 1999, Spatial accuracy assessment - Land information uncertainty in natural resources: Chelsea, Michigan, Ann Arbor Press, 455 p.

Merewether, E.A., 1996, Stratigraphy and tectonic implications of upper Cretaceous rocks in the Powder River Basin, northeastern Wyoming and southeastern Montana: U.S. Geological Survey Bulletin 1917-T, 92 p.

Miller, W.R., ed., 1999, Coalbed methane and the Tertiary geology of the Powder River structural basin Wyoming and Montana: Wyoming Geological Association Field Conference Guidebook, v. 50, 256 p.

Montgomery, S.L., 1999, Powder River Basin, Wyoming-An expanding coalbed methane (CBM) play: American Association of Petroleum Geologists Bulletin, v. 83, p. 1207-1222.

Mowrer, H.T., and Congalton, R.G., eds., 2000, Quantifying spatial uncertainty in natural resources, theory and applications for GIS and remote sensing: Chelsea, Michigan, Ann Arbor Press, 244 p.

Rice, C.A., Bartos, T.T., and Ellis, M.S., 2002, Chemical and isotopic composition of water in the Fort Union and Wasatch Formations of the Powder River Basin, Wyoming and Montana-Implications for Coalbed Methane Development in Schwochow, S.D., and Nuccio, V.F., eds., Coalbed methane of North America, II: Denver, Colo., Rocky Mountain Association of Geologists, p. 53-70.

Rice, C.A., Ellis, M.S., and Bullock, J.H., Jr., 2000, Water coproduced with coalbed methane in the Powder River Basin, Wyoming — preliminary compositional data: U.S. Geological Survey Open-File Report 00-372, 20 p.

Rice, C.A. and Nuccio, V., 2000, Water produced with coal-bed methane: U.S. Geological Survey Fact Sheet FS-156-00, 2 p.
Schwochow, S.D. and Nuccio, V.F., (eds.), 2002, Coalbed Methane of North America, II: Denver, Colo., Rocky Mountain Association of Geologists, 108 p.

Steidtmann, J.R., 1993, The Cretaceous foreland basin and its sedimentary record: in Snoke, A.W, Steidtmann, J.R., and Roberts, S.M., eds., Geology of Wyoming: Geological Survey of Wyoming Memoir No. 5, p. 251-271.

U.S. Department of the Interior, 2002, Draft Environmental Impact Statement and Draft Planning Amendment for the Powder River Basin Oil and Gas Project: Buffalo, Wyo., Bureau of Land Management, Wyoming State Office, WY070-02-065, v. 1, variable pagination.

U.S. Environmental Protection Agency, 2004, Great Lakes Water Volume: accessed May 8, 2004, at URL http://www. epa.gov/glnpo/statsrefs.html.

Whitehead, R.L., 1996, Ground water atlas of the United States, Segment 8, Montana, North Dakota, South Dakota, Wyoming: U.S. Geological Survey Hydrologic Investigations Atlas 730-I, 24 p.

Whipkey, C.E., Cavaroc, V.V., and Flores, R.M., 1991, Uplift of the Bighorn Mountains, Wyoming and Montana-A sandstone provenance study: U.S. Geological Survey Bulletin 1917, chap. D, 20 p. 
